\title{
Institutional Capital and Labour Devaluation: The Non-Recognition of Foreign Credentials in Germany
}

\author{
Harald Bauder*
}

\begin{abstract}
The non-recognition of foreign credentials channels many international migrants into occupations below their skill levels. I examine processes of credential devaluation among so-called Spätaussiedler who migrated from Eastern Europe to Germany. An empirical study, involving an interview survey of $N G O$ administrators, government bureaucrats, and employers in Berlin, suggests that institutional processes of credential recognition are intertwined with cultural processes of distinction. The study illustrates how institutional labour market regulation links with forces of social reproduction and the cultural exclusion of migrants. JEL classifications: J3I, J6I
\end{abstract}

\section{Introduction}

International migrants often find themselves in stopgap employment in the labour markets of their places of destination (e.g. Castles 2000, Reitz 2003, Waldinger 200I). In this paper, I explore the devaluation of immigrant labour in Germany. Of particular interest is the non-recognition of foreign credentials among so-called Spätaussiedler who migrated from Eastern Europe and the former Soviet Union. I link the non-recognition of credentials to

* University of Guelph. The German Academic Exchange Service (DAAD) and the Social Sciences and Humanities and Humanities Research Council of Canada (SSHRC) funded this research. I thank Rainer Münz for hosting me at the Humboldt University of Berlin, Carsten Foertsch for research assistance, and Randy McLeman for comments.

Correspondence address:

Harald Bauder, Associate Professor, Department of Geography, University of Guelph, Guelph, Ontario NIG 2WI, Canada, e-mail: hbauder@uoguelph.ca

Received 10 Nov 2003, accepted 12 Jan 2005

(C) INTERVENTION. Journal of Economics, Vol. 2 (2005), No. 1, p. 75-93 
wider processes of social distinction, and view the devaluation of immigrant labour as a mechanism of the social reproduction of privileged positions held by non-migrant labour. After the fall of the Berlin Wall in 1989, the Federal Republic of Germany has received a sharply increasing stream of returning migrants of German origin, or Spätaussiedler, from Eastern Europe and the former Soviet Union. Legally these migrants are not perceived as immigrants but as fellow citizens (Gassner 1997, Koopmans 1999). German law (i.e. the Bundesvertriebenengesetz [BVFG] \$4) defines as Spätaussiedler those ethnic Germans »who left the former Soviet Union, Estonia, Latvia or Lithuania after December 3I, I992 through formal procedure." (Juris 2003, my translation) The law also specifies that applicants have to demonstrate their commitment to the German nation through their ancestry, knowledge of the German language, education, and culture (BVFG \$6). Once accepted as Spätaussiedler, they are considered German citizens with unrestricted access to the labour market and with entitlement to the recognition of their foreign educational and occupational credentials.

Despite these privileges, Spätaussiedler have experienced difficulties in the German labour market (Münz et al. 1997). A problem for some Spätaussiedler, such as former workers in the oil industry, is that their occupations do not exist or are not in demand in Germany, such as former workers in the oil industry. Other Spätaussiedler, however, are denied work in their own occupations due to the non-recognition of their foreign occupational and educational credentials (Münz et al. 1997: IIs ff., Koch 200I: I9 ff.). Although they are legally entitled to credential assessment, the practice of non-recognition apparently excludes Spätaussiedler from employment in the upper labour market segment.

The empirical study, involving an interview survey of administrators of non-governmental organizations (NGOs), government bureaucrats, and employers, took place in the city of Berlin. The results of the survey illustrate the role of institutions in the devaluation of migrant labour. I interpret these results in light of theories of social reproduction.

\section{Background}

\section{I Spätaussiedler in the labour market}

57 percent of the Spätaussiedler who arrived in Germany in 2002 were income earners and/ or in the labour force prior to settling in Germany. This figure can be disaggregated into 58.9 percent for men and 55.8 percent for women. The remaining Spätaussiedler were either children, students, retirees or they were not in the labour force. Among those in the labour force, 42.7 percent were in service occupations, particularly in social, administrative, transportation, health and sales occupations. Another 36.8 percent had industrial and trade occupations, especially as mechanics, locksmiths, and industrial helpers; I0.4 percent had technical occupations, including engineer and technician (Bundesverwaltungsamt 2003).

Tracking the labour market performance of these newcomers after their arrival in Germany is difficult. The government does not legally distinguish between Spätaussiedler and other Germans, and therefore does not provide separate labour market statistics for Spätaussiedler and native-born Germans. Statistical information on the labour market perform- 
ance of Spätaussiedler is therefore limited. Nevertheless, some studies indicate that only about I6 percent of Spätaussiedler are employed (Chrustaleva 2002), and most of those who are employed fill positions that are unattractive to German-born workers (Greif et al. 1999). While about half of the employed Spätaussiedler still work in fields related to their pre-migration occupation, most work below their original qualifications (Münz et al. I997: I2I ff.). These studies thus suggest that a large portion of Spätaussiedler are excluded from effective participation in the labour market, and those who do find employment often suffer from the devaluation of their qualifications.

\subsection{Institutional regulation}

Non-orthodox economics, such as the regulation school (e.g. Boyer 1990, Tickell/Peck I995), has long challenged the idea that economies are self-regulating systems that gravitate towards a general equilibrium state. Among non-orthodox labour market researchers, the social regulation of labour market has received particular attention (e.g. Hanson/Pratt 1995, Peck 1996, Bauder 2002). In this paper, I examine how labour markets are institutionally regulated. While the term institution often includes a range of social configurations (e.g. family, gender, community, etc.), my interest lies in government institutions and regulatory bodies responsible for setting occupational entry conditions. For international migrants, such as Spätaussiedler, an important occupational entry condition is the recognition of their foreign credentials. The institutions responsible for foreign credential recognition control which migrants have access to certain occupations.

The institutional processes associated with credential recognition challenge human capital theory. This theory suggests that personal income and occupation reflect investment in education and training. Immigrants supposedly upgrade their human capital as they improve their language skills and assimilate into the host society. Over time, they therefore move upward in the labour market (e.g. Chiswick 1978, Borjas 1985). In this paper I suggest that education and skills do not always provide access to higher-wage occupations. Rather, institutional processes define whether a worker is eligible to work in a particular occupation. Furthermore, eligibility is a function of pre-market processes of social distinction. For example, workers who do not possess the institutional authority to practice medicine are excluded from medical occupations, whether they possess the necessary practical skills and theoretical knowledge - that is the human capital - or not. Moreover, whether or not they receive the privilege to practice depends on where they obtained their skills and knowledge. In this case, institutional capital rather than human capital regulates access to occupations.

Formal institutions are an important element of social reproduction. Bourdieu (I984, Bourdieu/Passeron 1977) refers to the term institutionalized cultural capital to describe how a privileged elite in France relied on educational credentials to distinguish themselves from lower classes who did not have access to the prestigious institutions of higher education. The democratization of higher education in Western Europe and North America during the post-WW II period strengthened the role of institutional capital in regulating the la- 
bour market (Collins 1979, Brint/Karabel 1989). Educational diplomas and occupational certificates have become central requirements for employment in most occupations.

While the popularization of the education system may have broken the monopoly access of social elites to occupations in the upper segments of the labour market, it did not eliminate the institutional exclusion of some groups. Of particular interest in this paper is the exclusion of migrants. The non-recognition of foreign educational and occupational credentials excludes migrants from occupations that require these credentials, even when they possess technical expertise and practical experience similar to holders of domestic credentials. Thus, the institutional capital of domestic credentials serves as a mechanism of regulation that privileges domestic workers and excludes migrants.

The term institutional capital implies that institutional and economic processes cannot be easily separated from each other. In fact, Bourdieu (1986) explains that various forms of monetary and non-monetary capital are inter-related elements of a wider system of social and economic relations. For example, institutional capital can be transformed into monetary capital through entrance into a high-paying occupation. Below, I will draw attention to the economic nature of institutional processes by using terminology that is usually used to describe economic processes. For example, the non-recognition of foreign credentials constitutes a devaluation of labour.

The non-recognition of foreign credentials as a mechanism of labour devaluation is not unusual in countries that receive large numbers of foreign migrants (e.g. Geddie 2002, Bauder 2003). In Germany Spätaussiedler present an interesting case, in that, as German citizens, they enjoy rights and privileges unavailable to other migrant groups (Morris 2002: 28-52), yet they still fall victim to the double standard of domestic versus foreign credentials. In particular, Spätaussiedler have full legal access to the labour market and obtain economic integration assistance (Bundesministerium des Innern 2002). In some cases, Spätaussiedler receive preferential treatment relative to other Germans - for example when applying for small business loans (Juris 2003: BVFG \$I4). Regarding credential recognition, different criteria apply to Spätaussiedler and non-German migrants. Spätaussiedler have a legal right to the full assessment and accreditation of their vocational qualification to manage a small business and offer vocational apprenticeships - a right that is denied to foreigners and naturalized migrants (Juris 2003: BVFG \$I4). Despite these privileges, Spätaussiedler still experience considerable labour market disadvantages due to the nonrecognition of foreign credentials (Koch 200I: 19-22). The focus on Spätaussiedler allows me to emphasize the role of institutional capital in disadvantaging workers who otherwise enjoy all legal rights and privileges.

\section{Study area and methodology}

The empirical investigation undertaken in this study focuses on the city of Berlin. To share the cost and burden of integration, the federal government disperses Spätaussiedler spatially among regional states (Bundesländer). Berlin now receives 2.7 percent of all Spätaussiedler 
arriving in Germany (Juris 2003: BVFG \$8), and roughly 40,000 of the 2.5 million ethnic Germans from the former Soviet Union who settled in Germany between 1988 and 1998 (Bade/Oltmer 1999: 2I). The arrival of these newcomers constitutes an additional challenge to the already strained local economy of the unified Berlin.

The state and structure of Berlin's economy influence the integration of Spätaussiedler into the labour market. With unification, two previously separate economies and labour markets were merged. The Western part of the city lost federal transfer payments designed to sustain the geographically isolated economy of the former West Berlin. At the same time, a significant portion of the Eastern manufacturing industry closed its operations in light of increased competition. Skilled workers subsequently flooded the local labour market and diminished opportunities for newly arriving migrants (Häußermann/Kapphan 2000). The oversupply of labour is reflected in extraordinarily high unemployment rates. In August 2002, when empirical research for this study was conducted, the unemployment rate in Berlin was 17 percent (Doelfs 2003).

The economic situation of Spätaussiedler who settled in Berlin is worse than that of other residents. Recent figures indicate that 53 percent of women and 47 percent of men were unemployed. Only about Is percent are legally employed, and women are less likely to find employment than men. Many of the men and women who are employed work in low-skill jobs with considerable health risks and few chances for occupational upward mobility. While some workers, especially in technical professions, manage to secure jobs in their pre-migration occupations, only about half of those who find employment at all work in their previous occupations. Sixty-eight percent of Berlin's Spätaussiedler do not possess any recognized occupational certification. Unemployment among Spätaussiedler concentrates disproportionately in regulated occupations that require certification, such as teaching and the trades (Bundesanstalt für Arbeit 200I).

In the empirical analysis below, I draw on an interview survey of 24 government bureaucrats, administrators of non-governmental organizations (NGOs), labour market and settlement counsellors, and employers in Berlin who deal with Spätaussiedler and/or some aspect of their situation in the labour market. The survey sample was developed from reference catalogues that list services for migrants (Ausländerbeauftragte des Senats von Berlin 2000, 2002a, 2002b, 2002c) and through word of mouth. The survey was designed to facilitate exploratory research. Interviews followed a semi-structured technique that allowed the interviewer to probe for specific issues, and that enabled respondents to elaborate on problems not included in the pre-designed interview guide. In the initial interview guide, the development of questions followed the relevant literature. Later in the research process, I modified the interview guide as my grasp of the material and the issues involved deepened. The insights gained during the research process also shaped the sample of institutions and respondents. The interviews varied in length, but they were on average 70 minutes long. All interviews were conducted in German. They were taped and transcribed. The quotes below are my own translations. 


\section{Results \\ 4.I Labour market segmentation of Spätaussiedler}

The interview respondents generally agreed that Spätaussiedler are confronted with considerable difficulties in the German labour market. Respondents acknowledged the high unemployment rates of Spätaussiedler and confirmed that most Spätaussiedler who have jobs work in low-skill occupations. For example, respondents describe the following scenarios:

"Most of those who we place into the first [i.e. unsubsidized] ${ }^{\mathrm{I}}$ labour market are people with low qualifications, who work in cleaning firms, in small businesses. And yes, they are regularly exploited and work for very low wages."

"[Spätaussiedler] take on the lowest jobs. They receive the lowest hourly wages. [They assume] work that nobody else wants. Cleaning women, many men work for cleaning firms, for example in the $S$-Bahn [light-rail urban-transit system], in building cleaning. Construction, many with secondary education work in installation."

"Everyone works on an entry-level step. They get eight Marks ${ }^{2}$ an hour, or work in construction."

Respondents also mentioned that Spätaussiedler often work as truck drivers, manual labourers, geriatric nurses, and in temp agencies. The manager of a settlement agency remarks, "temporary agencies like to hire [Spät]aussiedler because of their low wage level."Another informant implies that the low wage levels of temp workers do not reflect the value of their labour:

"Temp agencies take advantage of the situation by buying [Spät]aussiedler for eleven

Marks and renting them for 20 Marks per hour. A lucrative business."

Disproportionate representation in temporary employment indicates the role of Spätaussiedler as a "flexible" workforce at the bottom of the labour market (Theodore 2003, Peck/ Theodore 200I).

\subsection{The non-recognition of credentials}

A major contributing factor to the devaluation of Spätaussiedler's labour and their segmentation into low-wage and low-skill occupations is the non-recognition of their educational credentials and employment experience. German law states explicitly that Spätaussiedler's

I In the German context, the first labour market usually refers to the unsubsidized labour market. The second labour market includes positions that are government-subsidized to create employment opportunities that would otherwise not exist.

2 Although the official currency at the time of the interviews was Euro $(€)$, many respondents still used German Marks (DM) when they discussed price and wage levels. One DM corresponds to $€ 0.5$. 
"exams and proof of qualification are to be recognized, if they are equivalent to the corresponding exams and proof of qualification« in Germany (Juris 2003: BVFG \$IO). Despite this legislation, most interview respondents still saw credential non-recognition as a major labour market barrier for Spätaussiedler. For example:

"In the context of labour market integration the non-recognition of degrees is an important topic. It is a gigantic problem [for Spätaussieder who have a] high school diploma, university degree, or employment experience. There are people who already have 20 years of employment experience [...] and nothing is recognized."

"This is actually the most serious problem about taking up employment. The degrees that many migrants obtained in their home countries are not recognized here. We have a [client] who managed five or six large canteens with her husband in their hometown. Their job is not recognized and her husband works as kitchen helper. This is really the biggest problem."

Educational credentials obtained in the former Soviet Union and Eastern Europe are generally acknowledged, but respondents suggested that they are devalued and accepted at a lower level only. A settlement counsellor says:

"If they have the Spätaussiedler documents [Spätaussiedlerausweis], then their education is of course recognized. A secondary educational degree [Abitur] is recognized as intermediate school [Realschule], two years of college [Hochschule] are recognized as a high school diploma. That's quite something."

Similarly, occupational qualifications are frequently not recognized. German law regulates occupations in the fields of health, pedagogy, food production and inspection, agriculture and forestry, law, accountancy as well as technical and trade occupations. In addition, all government employment is regulated. To practice in regulated occupations an employee requires specific degrees and/or certification. Although Spätaussiedler have the formal right to the recognition of their certificates, non-accreditation still constitutes a significant hurdle to employment in regulated occupations. ${ }^{3}$ If degrees and certificates are formally recognized, it is often at a lower level. For example, a respondent reports:

„Engineers are generally recognized as technicians. The ones with Technikum, which was between vocational school [Berufsschule] and college [Hochschule], are relegated to trades occupations."

For accreditation, the structure and contents of the foreign program is required to match the equivalent German certificate program (KMK 1995: A.I). A decree of the Standing Conference of the Ministers of Education specifies that workers with technical degrees (Techniker) from the former Soviet Union correspond to the lower category of skilled workers

3 Since the accreditation of foreign credentials is the responsibility of state governments ( $L a ̈ n d e r)$, Spätaussiedler usually apply for accreditation after they have been assigned to a place of residence. In most cases, accreditation cannot be guaranteed prior to migration. 
(Facharbeiter) in Germany (KMK 2003c). An employee in the Senate Administration of Berlin explained that her office is bound by this decree.

The interviewees generally differentiated between regulated occupations, such as educators and lawyers, in which recognition is nearly impossible, and non-regulated occupations, in which employers are not bound by law to hire workers with specific credentials (KMK 2003a). However, even in the occupations not regulated by government, Spätaussiedler rarely find employment in their field because employers do not regard foreign credentials as equal to German credential in the same occupation. An employment counsellor suggests that Spätaussiedler in non-regulated occupations face an additional disadvantage because they are expected to enter the labour market without additional training.

"[Many migrants] have formal credentials [in a non-regulated occupation], well then, they do not need further training or education. The career guidance officer says: , You have credentials. Here are addresses. Simply apply.« But, of course, businesses do not take [migrants] who obtained their credentials [abroad]. The formal paper is not enough if one has not gone through the local system."

Employers' belief in the superiority of the German education and training systems translates into the devaluation of Spätaussiedler's credentials, even in occupations not regulated by the state.

Another problem frequently mentioned in the interviews is the non-recognition of foreign work experience. One problem is that workers have experience in a field outside of their training that did not match their credentials. An employment counsellor remarks:

»In the Soviet Union, one studied in a certain subject and then worked completely outside of this subject. For example, I counselled a physics teacher who worked in a wastewater treatment plant and had ten years of experience. And he had problems [finding employment] in a treatment plant here because he did not have the qualifications."

However, even workers with work experience in their field of study often get no credit for their experience because their degrees are not accredited. An employment counsellor who resettled from Russia finds herself in the bizarre situation that her work experience was invalidated because she did not acquire her training and experience in the exact sequence demanded by German regulators:

"In Russia an academic education is followed by practical training, but the practical hours are insufficient for Germany. It had to be more, and therefore it is not recognized. For example, in Russia I was a tailor. I attended a technical vocational school (technische Berufsschule). After school, I worked in the evenings. I worked for seven years, but here it is not recognized because there were too few practical hours in practical training. That I worked seven years did not make a difference. I do not have practical experience!«

This same respondent continues to explain that similar problems exist in other occupations: 
"Exactly the same happens with doctors who worked in the best clinics in Moscow and who do not have a chance here. [...] Doctors, university teachers, and educators, they have almost no chance here and have to start from the beginning."

In these occupations, work experience is only recognized if both practical and academic components of the degree program match those of the equivalent German degree. Decades of experience can be invalidated if the incorrect amount of practical training was completed in the context of the degree program.

The devaluation of educational and educational credentials often triggers a downward spiral of diminishing labour market opportunities. As Spätaussiedler struggle to complete the necessary programs to qualify for employment in their field, they are removed from their occupations, and their practical experience becomes outdated. The administrator of an NGO which helps newcomers to settle in Berlin elaborates:

"The application for relocation [to Germany] is for many [ethnic Germans] associated with the withdrawal from their work. [...] They come to Germany and are busy for three or six months with their documents and so on. Then they participate for six months in a German-language program. So one year passes, without the possibility for them to work. [...] Altogether there is a minimum period of two years more often four to five years - in which they do not work. In this situation they are devalued in the labour market because their knowledge of their subject is invalid, it is obsolete. If their resumé indicates sunemployed since 1998 , you won't be able to place this person."

\subsection{Legitimating credential non-recognition}

The conventional explanation for the devaluation of foreign credentials is that the contents and length of education and training differ between Germany and foreign countries. German law specifies that the accreditation of foreign educational degrees is only possible if a corresponding degree exists in Germany (KMK 2003b). An education counsellor explains that some of her clients from the former Soviet Union have degrees in subjects "[...] that do not exist in Germany, for example, Methodology and Psychology in Primary Education." In these cases, accreditation is not possible. If a comparable degree exists in Germany, then both degrees must represent the same number of school years. In the former Soviet Union, a degree from a secondary educational institution is typically obtained in a shorter time period than in Germany. As several respondents remarked, a degree from the former Soviet Union should therefore not be equated with a German degree: "In Russia there are only ten or eleven grades, that's not enough for here«, or "grade twelve and thirteen are missing to acquire the Abitur."

German regulations allow NGOs to offer supplemental programs to compensate for the gap in length of education (Anabin 2003: 5.3). For example, the Otto-Benecke Foundation offers a two-year educational program that enables migrants with a secondary diploma from Eastern Europe to obtain the educational standard required for entrance into German 
universities. However, most migrants who qualify for such programs do not participate in these programs or fail to obtain the German equivalent to a secondary diploma.

The non-recognition of occupational credentials is also justified by differences in content between German and foreign training programs. An administrator in the Office for Employment (Arbeitsamt) stresses the significance of equivalent contents:

"Regarding the recognition of certificates, one must consider the quality of training in comparable occupations. The content often differs, so that comparability cannot easily be established. During the review the content is properly assessed: what was taught, and is it comparable to the knowledge and skills of German training? If yes, the certificate will be recognized. If no, it will not be recognized as equivalent."

An official in the Berlin Senate Administration suggests that the German technical degree is superior to foreign technical degrees:

"In Germany, [technicians] need vocational training and practical training, and then the technical degree. And this is not so [in the Commonwealth of Independent States], where someone can pursue a technical degree immediately after ten years of school. They therefore lack enormous practical knowledge."

Another example are teachers. A settlement counsellor explains:

"The situation with teachers is that the degree is completed with two main subjects.

In the Soviet Union there was only one subject. [Spätaussiedler] who settle here cannot become teachers."

The ideological orientation of training and educational programs is also a criterion for the recognition of credentials. An NGO administrator notes that this criterion affects especially teachers (who already have difficulties because they specialize in one subject rather than the required two as required in Germany): "Teachers aren't recognized at all because the ideology isn't right." Other occupations are also affected:

"What is generally not recognized are certificates in the field of economics. [...]

Lawyers and graduates in the arts and humanities - one can list entire groups - are

handicapped in this way."

\subsection{Institutional practices and devaluation}

The authority of credential recognition rests largely with the state. In this section I present two brief examples to illustrate the role of different government institutions in the devaluation of migrant labour. The first example is the occupation of medical doctor which is among the most tightly regulated occupations by the state. A particular characteristic of medical doctor is that certification alone does not provide access to employment. In addition to certification, the Berlin Senate Administration must grant a license to practice medicine to the individual worker (Approbation). To obtain this licence, an applicant must 
have completed six years of medical education at a university or equivalent and participated in 18 months of practical training. Applicants must also be in good physical health and have no criminal record. Permanent licences valid within Berlin are only issued to German citizens and EU nationals (Landesamt für Gesundheit und Soziales 2003). Between I996 and 2002, the Senate Administration of Berlin issued between 900 and I,Ioo medical licences (Medizinischer Newsservice 2003).

Medical doctors who arrive as Spätaussiedler are German citizens and therefore fulfil the citizenship requirement for obtaining the license to practice. An administrator in the office responsible for issuing the license to practice medicine in Berlin confirms the formal eligibility of Spätaussiedler for the license to practice:

"[A Spätaussiedler] normally comes here and can say: I'm a medical doctor and want to work here. Can I do that? ' Then we examine his/her education, citizenship, police record, Aussiedler-status; then we say: >Positive! You are German, you are healthy and without criminal record and we assess your education in this manner.«

The final remark by this respondent indicates that the appraisal of education constitutes the main problem for Spätaussiedler in obtaining the licence to practice. The same respondent noted later in the interview, "usually, the [medical] education of the former USSR cannot be considered equal.« He explains:

"One should not forget that in many countries credentials for medical doctor can be obtained much more easily. If someone was educated in the USSR, then one year of practical activity had to be performed as a part of the degree. Then one was already in their view something like a medical specialist. Here the minimum practical training period [for medial specialist] is four years."

If the quality and the content of the foreign educational program are not considered equal, a license to practice will not be issued.

To give Spätaussiedler the opportunity to upgrade their skills to meet domestic medical standards, the Berlin Senate Administration can issue a one-year limited work permit to practice. The one-year work permit can be renewed to a total of up to four years. With upgraded skills, the Spätaussiedler would be eligible for an unlimited license. ${ }^{4}$ An informant in the Berlin Senate Administration explains that the medical education of Spätaussiedler is frequently assessed as "not equivalent «, even after practising for four years in Germany with a time-limited work permit. In this case, a doctor will not receive the unlimited license and has to end his/her career. An employment counsellor reports about a client who was a medical doctor in Russia, but practically has

4 New legislation restricts labour market access to foreign trained doctors even further. New regulations for Approbation recognizes only the number of years of medical education obtained abroad, but not the completed exams. Spätaussiedler who received their medical training abroad are now subjected to examinations based on German professional standards (Bundesärztekammer 2003). 
"no chance [for Approbation]. She would need to complete twelve exams in German language. She already said before the first exam that she would not pass. It is unrealistic for her [to continue] as a medical doctor.»

Along the same lines, an administrator of an education and training program says:

"Medical doctors have almost no chance to obtain a license. When a doctor from Russia arrives, then we have experienced very dramatic situations, that highly skilled people with an incredible amount of experience were the last [people] who had a chance of employment. [Now] they work far below their qualifications."

The second example illustrates the role of the Office of Employment (Arbeitsamt) as a key institution in the devaluation of labour. The interviews suggested that this office's practices relating to career counselling and labour market placement effectively disadvantage many Spätaussiedler in the labour market. For example, counsellors in the Office of Employment regularly advise Spätaussiedler whether they should pursue additional education and training to become accredited in their previous occupations, or whether they should pursue alternative careers. Some of my informants believe that the Office of Employment actively channels Spätaussiedler into low-skill employment rather than encouraging them to get their credentials accredited. An officer in an NGO for Spätaussiedler says:

"The office of employment says for example to doctors, engineers and so on: >Forget it, care for the elderly is called for. I also know a librarian, she never had anything to do with old and sick people and then retrained to become a geriatric nurse. Everyone becomes a geriatric or medical nurse. The librarian was in her mid forties and had never seen blood. In the middle of her program she collapsed and had to be picked up [by one of our staff]."

To a large degree, the practices in the Office of Employment that channel Spätaussiedler into lower-skill occupations reflect regulations imposed by other institutions. For example, if foreign credentials are not recognized by the Berlin Senate Administration, then the Office of Employment cannot refer clients to their previous occupations. In addition, an objective of the Office of Employment is to introduce clients into the social insurance system where they are eligible to claim benefits after one year of regular employment. If employment in the previous occupation is not immediately possible because of non-accreditation, then Spätaussiedler are typically referred to low-skill positions in order to qualify for social insurance benefits. An employment counsellor in an NGO that co-operates closely with the Office of Employment explains:

"Sometimes we say, OK, if nothing else works, then you will clean one year. Then you will have at least acquired the status of a regularly registered unemployed person at the Office of Employment. You will receive services from the Office of Employment. The Office of Employment is obligated to serve you. The state simply recognizes you differently, no matter whether someone worked as a janitor, newspaper carrier, or packer." 
The common effect of this effort to integrate Spätaussiedler into the social insurance system is occupational deskilling. In this case, labour devaluation is a concession made by Spätaussiedler to ensure economic security and gain access to the social welfare system.

\subsection{The political economy of labour devaluation}

The devaluation of labour, associated with the non-recognition of educational and occupational credentials and the invalidation of work experience, affects mostly migrants in the upper segments of the labour market, where occupations are more likely to be regulated. One respondent comments on this effect:

"The higher the level of education, the lower the chances for [labour market] integration. An absurd phenomenon that we experience. One can observe that the chances [for integration] are higher among the ethnic Germans from Russia who come from regions with relatively low levels of education."

Not only are workers with devalued or invalidated credentials relegated to lower labour market segments, but their skills may be not be suited for employment in semi-skilled occupations. Consequently, many find jobs only in the very lowest segment of the labour market. The director of a settlement service organization that hired its own clients in an effort to integrate them into the labour market explains:

"We used to [hire Spätaussiedler] in the beginning - for reasons of solidarity. But that was a mistake because we did not realize that we require German office clerks for German office work and not Soviet engineers. With German engineers this wouldn't work either. [...] These are simply things that require a little experience, an occupational qualification."

In the eyes of most interviewees the degradation of highly skilled Spätaussiedler to employment in a low segment of the labour market is a common phenomenon. Respondents reported numerous examples that illustrate this phenomenon. For example:

"[My client] is a cleaning woman. But she completed university and has 20 years of experience in precision engineering. She is a senior engineer. And the representative at the Office of Employment (Arbeitsamt) could not say anything else [but] ,we referred her to this [occupation], as cleaning woman! We often have cases like these."

"No teacher is recognized as teacher. Therefore they [clients with teaching degrees] go into construction; janitor is a common occupation; room maid."

Only when highly skilled and experienced workers stay within their general field of training do they have a chance to escape relegation into the lowest segment of the labour market. A career counsellor remarks that she advises her clients to pursue this strategy:

"Many [Spätaussiedler] work below qualifications and not in their [previous] occupation, but electrical engineers work as electricians, medical doctors as nurses, or they retrain as geriatric nurses." 
Another respondent states that "many [medical doctors with foreign credentials] try to stay close to the medical profession by working in nursing. «And a settlement counsellor reports about the experiences of two of her clients:

" I have managed for 23 years a gynaecological section [in a hospital] and now I should work as a midwife-assistant. This woman shed tears. And an orthopaedist was offered a position as plasterer in a hospital.«

In these cases, Spätaussiedler work in subordinate occupations but are still able to apply their technical expertise and training.

The subordination of highly qualified workers into less-qualified, yet related, occupations is facilitated by labour market policies that regulate the upper segments of the labour market more tightly than the lower segments. For example, some migrants perform jobs where they apply their skills, but are paid relatively low wages because they are denied their professional titles. An informant explains how this process works in the context of the medical field:

"While the title and the practice of academic [medical] occupations are protected, occupations [in non-academic occupations, i.e. nursing or massage therapy] can be practised, but the job title may not be used. The migrant can therefore come here and does not need accreditation. He [sic] only needs someone who lets him work. If he doesn't have the title, then, in most cases, he will be subordinated in his labour contract to someone with permission to carry the job title."

In this scenario, the main beneficiaries of labour devaluation are employers, who get highly skilled and experienced workers for lower wages than German-trained workers would demand. In the same vein, several respondents reported that employers often take advantage of the fact that foreign credential are not recognized and employ highly qualified Spätaussiedler as cheap apprentices. A settlement counsellor, for example, complains about employers who hire her clients so long as they participate in job training programs, but then refuse to hire them as regular employees:

"We have a partner [in the private industry]. We start and provide occupational counselling and refer our participants there. [...] Of 80 participants about 20 are actually working - but not always permanently. Possibly they return after the probationary period. The firms take someone else, because they are cheaper during the probation period."

Other informants observe that employers receive excellent workers who work as interns for low or no wages:

"I know from our young interns that [employers] look closely at the [skills of applicants]. Someone has a company for agricultural machines, and the young man has university education and work experience exactly in the field required by the employer." 
"We have a lawyer here. He passed his first state examination in Irkutsk, which was recognized. He attempted the second state examination in Germany but failed. The man is highly intelligent, but he could not cope with the exams from a language point of view. [...] He [now] completes an internship once a week with a lawyer [...] where he participates in communication with clients."

Skilled and educated Spätaussiedler do not unlearn their skills or forget their knowledge. Rather, their skills and education are devalued, preventing them from claiming wages that reflect their human capital. Institutional processes associated with credential non-recognition thus supplies a labour force rich in human capital cheaply to German employers.

\section{Conclusion}

"How many studies like this have there been? I think every one already knows what the cause is: level of education." (Administrator in the Federal Office of Labour, Bundesanstalt für Arbeit)

This quote illustrates that the problem of unemployment and segmentation of migrants into low-wage occupations is commonly attributed to a lack of human capital. The above analysis revealed that a key labour market barrier for Spätaussiedler indeed relates to educational and occupational credentials. However, the problem for Spätaussiedler is not so much that they lack education or skills, but that their institutional credentials are not recognized. In other words, the institutional capital Spätaussiedler acquired abroad is invalid or devalued in Germany. A settlement counsellor who has worked extensively with Spätaussiedler acknowledges this process, although he does not make the conceptual distinction between human and institutional capital:

„For every qualification there is a certificate. And Germany is certification-country, and what I don't have on paper does not exist. [...] There have been attempts in Germany to certify informal knowledge [i.e. experience, skills, etc.] through assessment. However, this is very complicated and expensive. One would need to certify every migrant. Who can afford this? Thus it leads to devaluation. Human capital is being destroyed."

Popular perception is that the labour market for migrants is driven by supply and demand. Accordingly, Spätaussiedler would find it easier to move into occupations where the supply of labour is relatively short. A government bureaucrat, for example, says the short supply of labour in accounting and sales occupations accounts for the "9o and 95 percent" success rate of accreditation among Spätaussiedler in these occupations. However, at the time of the interview an abundant supply of labour seems to have existed in these fields: the national unemployment rate for accountants was II.9 percent and for sales clerks I6.5 percent, compared to an average of 9.6 percent across all occupations (Bundesanstalt für Arbeit 2003). A more likely explanation for the occupational segmentation of Spätaussiedler 
is the institutional regulation of the labour market through the recognition of credentials and experience.

Which social processes and motivations underlie this system of institutional labour market regulation? Bourdieu (1984, Bourdieu/Passeron 1977) suggests that institutional capital in the form of credentials enables privileged groups to control their own reproduction. Bourdieu also argues that processes of social distinction are played out in varying institutional arenas, and that privileged groups strategically create and valorize new forms of capital to maintain their social and economic status. In the context of German immigration, Spätaussiedler constitute a new group of residents that possesses citizenship privileges and potentially threatens the status of native-born Germans. The latter therefore have an interest in defining entry regulations to the most prestigious occupations in such a manner that German-born and educated workers have access to these occupations while Spätaussiedler are excluded. Since Spätaussiedler are German, citizenship is not an effective instrument of distinction and exclusion. Rather, credential recognition (or non-recognition) has emerged as a more effective tool for this purpose.

Many state-regulated occupations, such as medical doctor, lawyer or engineer, are well paying and prestigious occupations in the upper segment of the labour market. By excluding workers with foreign credentials, German-born and educated workers maintain privileged access to these occupations. For example, in the medical field the German education system produces the number of doctors needed to fill the available positions. A bureaucrat in the Berlin Senate Administration explains that there is no need to offer licenses to foreign educated doctors:

"What works generally against issuing a licence to practice [to Spätaussiedler] is that there is a sufficient number of doctors in the state (Land) of Berlin who provide care. And therefore we do not need more doctors."

Demand for doctors is satisfied by the German education system, educating mostly Germanborn medical students. The process of credential non-recognition serves to keep foreigntrained Spätaussiedler out of this labour market.

Since upper-tier jobs are effectively reserved for German-educated workers, Spätaussiedler are pushed into less prestigious and lower-paying jobs. As noted by one respondent: "Many [foreign-trained] educators go into nursing in senior homes. That is exactly the type of work that the indigenous population does not want. "In other words, the near-monopoly access of German-born workers to the upper labour market segment and the devaluation of migrant labour help to structure the entire labour market, from top to bottom.

The institutional regulation of labour markets does not occur within an ideological vacuum. The representation of the German education and training system as superior to foreign systems has the effect that the foreign credentials of Spätaussiedler can legitimately be invalidated or subordinated in comparison with German credentials. A senior administrator in the Berlin Senate Administration recognizes the strategic nature of valorizing the local educational system and jokingly remarks: »Our educational system is held highly [laughter]. It is worth a lot - at least that is how it is always represented." 


\section{References}

Anabin (2003): Eingliederung von Berechtigten nach dem Bundesvertriebenengesetz (BVFG) in Schule und Berufsbildung, http://www.anabin.de [accessed Sept. 28, 2003]

Ausländerbeauftragte des Senates von Berlin (2000): Integration und Migration: Ein Wegweiser für Berlin, Berlin: Verwaltungsdruckerei Berlin

Ausländerbeauftragte des Senates von Berlin (2002a): Ansprechpartner/Informationen, Senatsverwaltung für Gesundheit, Soziales und Verbraucherschutz, http://www.berlin.de/ sengessozv/auslaender/ansprech.html [accessed Dec. I8, 2002]

Ausländerbeauftragte des Senates von Berlin (2002b): Die Ausländerbeauftragte informiert über wichtige Vereine in Auswahl, Senatsverwaltung für Gesundheit, Soziales und Verbraucherschutz, http://www.berlin.de/sengessozv/auslaender/vereine.html [accessed Dec. 18,2002 ]

Ausländerbeauftragte des Senates von Berlin (2002c): Top Berlin International: Ein Informationsforum, No. 7, Berlin: Verwaltungsdruckerei Berlin

Bade, Klaus J./Oltmer, Jochen (I999): Einführung: Aussiedlerzuwanderung und Aussiedlerintegration. Historische Entwicklung und aktuelle Probleme, in: Bade, Klaus J./Oltmer, Jochen (Eds.), Aussiedler: deutsche Einwanderer aus Osteuropa, Osnabrück: Universitätsverlag Rasch, pp. 9-5I

Bauder, Harald (2002): Work on the West Side: Urban Neighbourhoods and the Cultural Exclusion of Youths, Lanham: Lexington Books

Bauder, Harald (2003): »Brain Abuse«, or the Devaluation of Immigrant Labour in Canada, in: Antipode, Vol. 35, No. 4, pp. 699-717

Borjas, George J. (1985): Assimilation, Changes in Cohort Quality, and the Earnings of Immigrants, in: Journal of Labour Economics, Vol. 3, No. 4, pp. 2I-4I

Bourdieu, Pierre (1984): Distinction: A Social Critique of the Judgement of Taste, Cambridge: Harvard University Press

Bourdieu, Pierre (I986): The Forms of Capital, in: Richardson, John G. (Ed.), Handbook of Theory and Research for the Sociology of Education, New York: Greenwood Press, pp. $24 \mathrm{I}-258$

Bourdieu, Pierre/Passeron, Jean-Claude (1977): Reproduction in Education, Society and Culture, London: Sage

Boyer, Robert (1990): The Regulation School: A Critical Introduction, New York: Columbia University Press

Brint, Steven/Karabel, Jerome (1989): The Diverted Dream: Community Colleges and the Promise of Educational Opportunity in America, 1900-1985, New York: Oxford University Press

Bundesanstalt für Arbeit (200I): Strukturmerkmale der arbeitslosen Ausländer/Aussiedler/ Asylbewerber im Landesarbeitsbezirk Berlin-Brandenburg: Ergebnisse der Bestände der Arbeitslosen, Berlin: Landesarbeitsamt Berlin-Brandenburg

Bundsanstalt für Arbeit (2003): BerufeNet: Die Datenbank für Ausbildungs und Tätigkeitsbeschreibungen, http://berufenet.arbeitsamt.de/index.html [accessed Oct. 2, 2003] 
Bundesärztekammer (2003): Bundesgesetzblatt Jahrgang 2002, Teil I, Nr. 44: Approbationsordnung für Ärzte, http://www.bmgs.bund.de/download/gesetze/gesundheitsberufe/ approbation.pdf [accessed Oct. I, 2003]

Bundesministerium des Innern (2002): Innenpolitischer Bericht I998-2002, http://www.bmi. bund.de [accessed Oct. I, 2003]

Bundesverwaltungsamt (2003): Jahresstatistik Aussiedler und deren Angehörige, 2002, http:// www.bundesverwaltungsamt.de [accessed Jun. IO, 2004]

Castles, Stephen (2000): Ethnicity and Globalization: From Migrant Worker to Transnational Citizen, London: Sage Publications

Chiswick, Barry R. (1978): The Effect of Americanization on the Earnings of Foreign-Born Men, in: Journal of Political Economy, Vol. 86, No. 5, pp. 897-92I

Chrustaleva, Nelli (2002): Die psycho-soziale Situation russischer Emigranten unter besonderer Berücksichtigung der deutschen Spätaussiedler, in: Aussiedler in der Berliner Schule: Chancen und Probleme, Berlin: Berliner Landesinstitut für Schule und Medien, pp. 29-42

Collins, Randall (1979): The Credential Society: A Historical Sociology of Education and Stratification, New York: Academic Press

Doelfs, Guntram (2003): Silberstreif am Horizont: Arbeitslosenzahl im August leicht gesunken, in: Die Welt, Sept. 5, http://www.welt.de

Gassner, Hartmut (1997): Aussiedlerpolitik, in: Angenendt, Steffen (Ed.), Migration und Flucht: Angaben und Strategien für Deutschland, Europa und die internationale Gemeinschaft, Bonn: Bundeszentrale für politische Bildung, pp. 137-I53

Geddie, Kate (2002): Licence to Labour: Obstacles Facing Vancouver's Foreign-Trained Engineers, Research on Immigration and Integration in the Metropolis Working Paper Series, No. 02-2I, http://www.riim.metropolis.net

Greif, Siegfried/Gediga, Günther/Janikowski, Andreas (1999): Erwerbslosigkeit und beruflicher Abstieg von Aussiedlerinnen und Aussiedlern, in: Bade, Klaus J./Oltmer, Jochen (Eds.), Aussiedler: deutsche Einwanderer aus Osteuropa, Osnabrück: Universitätsverlag Rasch, pp. 8I-I06

Häußermann, Hartmut/Kapphan, Andreas (2000): Berlin: Von der geteilten zur gespaltenen Stadt? Opladen: Leske und Budrich

Hanson, Susan/Pratt, Geraldine (1995): Gender, Work and Space, London: Routledge

Juris GmbH (2003): Gesetz über die Angelegenheiten der Vertriebenen und Flüchtlinge (BVFG), http://bundesrecht.juris.de/bundesrecht/bvfg/gesamt.pdf [accessed Sept. 27, 2003]

KMK (Kulturministerkonferenz) (I995): Grundsätze der Bewertung und Anerkennung von Fachmittelschulabschlüssen aus Polen und anderen osteuropäischen Ländern bei Berechtigten nach dem Bundesvertriebenengesetz (Beschluss der Kulturministerkonferenz vom I0.9. I993), Bonn: Sekretariat der ständigen Konferenz der Kultusminister der Länder in der Bundesrepublik Deutschland

KMK (Kulturministerkonferenz) (2003a): Anerkennung ausländischer Hochschulabschlüsse für Berufszugang und Berufsausübung, http://www.kmk.org/zab/berufı2.htm [accessed Sept. 26, 2003] 
KMK (Kulturministerkonferenz) (2003b): Ausländische Schulbildung, http://www.kmk.org/ zab/schulo4.htm [accessed Sept. 26, 2003]

KMK (Kulturministerkonferenz) (2003c): Zentralstelle für ausländisches Bildungswesen, http:// www.kmk.org/zab/homer.htm [accessed Sept. 26, 2003]

Koch, Stefan (200I): Neue Nachbarn: Russlanddeutsche Lebenswege: Von Ost nach West, $2^{\text {nd }}$ Edition, Göttingen: Jochen Welt, Beauftragter der Bundesregierung für Ausländerfragen

Koopmans, Rudd (1999): Germany and its Immigrants: An Ambivalent Relationship, in: Journal of Ethnic and Migration Studies, Vol. 25, No. 4, pp. 627-647

Landesamt für Gesundheit und Soziales (2003): Ärzte/Ärztinnen, Senatesverwaltung Berlin, http://www.berlin.de/sengessozv/lageso/arztuebersicht.html [accessed Oct. I, 2003]

Medizinischer Newsservice (2003): Mehr Approbationen an Ärzte erteilt, May 19, http://www. berlin-ne.ws/medizin5/Nar905-05.htm [accessed Oct. I, 2003]

Morris, Lydia (2002): Managing Migration: Civic Stratification and Immigrants' Rights, London: Routledge

Münz, Rainer/Seifert, Wolfgang/Ulrich, Ralf (1997): Zuwanderung nach Deutschland: Strukturen, Wirkungen, Perspektiven, Frankfurt/Main: Campus

Peck, Jamie (1996): Work Place: The Social Regulation of Labour Markets, New York: Guilford

Peck, Jamie/Theodore, Nik (200I): Contingent Chicago: Restructuring the Spaces of Temporary Labor, in: International Journal of Urban and Regional Research, Vol. 25, No. 3, pp. $47 \mathrm{I}-498$

Reitz, Jeffrey G. (Ed.) (2003): Host Societies and the Reception of Immigrants, La Jolla, California: Center for Comparative Immigration Studies, University of California, San Diego

Theodore, Nik (2003): Political Economies of Day Labour: Regulation and Restructuring of Chicago's Contingent Labour Markets, in: Urban Studies, Vol. 40, No. 9, pp. I8II-I828

Tickell, Adam/Peck, Jamie A. (1995): Social Regulation after Fordism: Regulation Theory, Neo-Liberalism and the Global-Local Nexus, in: Economy and Society, Vol. 24, No. 3, pp. 357-386

Waldinger, Roger (Ed.) (200I): Strangers at the Gates: New Immigrants in Urban America, Berkley: University of California Press 
